\title{
Distribution and Application of Mycobactins for the Characterization of Species within the Genus Rhodococcus
}

\author{
By RICHARD M. HALL* $\dagger$ AND COLIN RATLEDGE \\ Department of Biochemistry, University of Hull, Hull HU6 $7 R X, U K$
}

(Received 25 September 1985 ; revised 8 November 1985)

Representatives of 11 species of Rhodococcus were examined for their ability to synthesize mycobactin, a lipid-soluble siderophore, following iron-limited growth on solidified glycerol/ asparagine medium. Rhodococcus bronchialis, $R$. terrae and $R$. rubropertinctus formed mycobactins, whereas the remaining species ( $R$. coprophilus, $R$. equi, $R$. erythropolis, $R$. rhodnii, $R$. rhodochrous, $R$. ruber, $R$. maris and $R$. luteus) failed to synthesize these compounds even under conditions of strictly iron-limited growth. The mycobactins from $R$. terrae and $R$. rubropertinctus showed close similarity by thin-layer chromatography and high-performance liquid chromatography and could be easily distinguished from that of $R$. bronchialis.

\section{INTRODUCTION}

The genus Rhodococcus (Zopf, 1891; Tsukamura, 1974) is now well-established and forms a phylogenetically recognizable group together with mycolic acid-containing actimomycetes belonging to the genera Caseobacter, Mycobacterium, Nocardia and Rhodococcus (Goodfellow \& Cross, 1984). The organisms in these taxa can be distinguished using a combination of morphological and chemical properties (Goodfellow \& Minnikin, 1981) but there is evidence that the genus Rhodococcus is heterogeneous. Thus, all of the species originally assigned to the genus 'Gordona' (Tsukamura, 1971), namely Rhodococcus bronchialis, $R$. terrae and $R$. rubropertinctus, have mycolic acids with between 48 and 66 carbons and major amounts of dehydrogenated menaquinones with nine isoprene units, whereas the remaining species, $R$. coprophilus, $R$. equi, $R$. erythropolis, $R$. rhodnii, $R$. rhodochrous, $R$. ruber, $R$. maris and $R$. luteus, have shorter mycolic acids and $\mathrm{MK}-8\left(\mathrm{H}_{2}\right)$ as the major isoprenologue. The two aggregate groups can also be recognized on the basis of antibiotic sensitivity patterns (Goodfellow \& Orchard, 1974), delayed skin reactions on sensitized guinea pigs and by polyacrylamide gel electrophoresis (PAGE) of cell extracts (Hyman \& Chaparas, 1977).

Methods for the identification of bacteria assigned to the genus Rhodococcus are as yet incomplete (Goodfellow \& Schaal, 1979). In this study we have cultured rhodococcal species under conditions of iron-limitation in order to encourage the possible production of the lipidsoluble siderophore, mycobactin. Mycobactins have a conserved structure and are speciesspecific for members of Mycobacterium and Nocardia (Ratledge \& Patel, 1976a, b; Hall \& Ratledge, 1984, 1985). The aim of this study was, therefore, to evaluate whether mycobactins are of value in rhodococcal systematics.

\section{METHODS}

Cultures and cultitation. Test strains (Table 1) were maintained on glucose/yeast extract/agar slopes (Gordon \& Mihm, 1962) or as dense suspensions of cells frozen in $20 \%(\mathrm{v} / \mathrm{v})$ glycerol at $-20{ }^{\circ} \mathrm{C}$ (Wellington \& Williams, 1978). Rhodococci were initially cultured in liquid glycerol/asparagine medium (Ratledge \& Hall, 1971) or

\footnotetext{
$\dagger$ Present address: Department of Biotechnology, Glaxo Group Research Ltd, Greenford, Middlesex UB6 $0 \mathrm{HE}$, UK
} 
Table 1. Rhodococci examined for mycobactin production

\begin{tabular}{|c|c|}
\hline $\begin{array}{c}\text { Laboratory } \\
\text { no.* }\end{array}$ & Designation and source of strains $\dagger$ \\
\hline $\mathrm{N} 361$ & R. ruber; M. Tsukamura, M-1. Type strain \\
\hline N54 & R. rhodochrous; ATCC 13808. Type strain \\
\hline N445 & R. rhodnii; P. Hill, Al.Type strain \\
\hline N11 & R. erythropolis; NCIB 9158. Type strain \\
\hline $\mathrm{C} 7$ & R. equi; D. Jones, C48; NCTC 1621. Type strain \\
\hline N744 & R. coprophilus: NCIB 11211. Type strain \\
\hline N659 & $+R$. terrae; NCTC 10669; M. Tsukamura, 3612. Type strain \\
\hline $\mathrm{N} 4$ & $\ddagger R$. rubropertinctus; NCIB 9664. Type strain \\
\hline N654 & $\ddagger R$. bronchialis; NCTC 10667. Type strain \\
\hline N1021 & R. maris; IMV 53; soil \\
\hline $\mathrm{N} 1025$ & R. maris; IMV' 678 \\
\hline $\mathrm{N} 1026$ & R. luteus; IMV 29; soil \\
\hline N 1027 & R. luteus; IMV 27; soil \\
\hline $\mathrm{N} 1028$ & R. Iuteus; IMV 187; soil \\
\hline N1029 & R. Iuteus; IMV 202; soil \\
\hline N 1032 & R. luteus; IMV 419 ; soil \\
\hline N 1034 & R. luteus: IMV 587 ; soil \\
\hline $\mathrm{N} 1035$ & R. luteus; IMV B 868 \\
\hline
\end{tabular}

* Laboratory numbers are those of the colection of Dr M. Goodfellow, Department of Microbiology, University of Newcastle upon Tyne, UK.

$\dagger R$. maris and $R$. luteus strains were received via Dr Goodfellow from Dr O. A. Nesterenko (D. K. Zabolotny Institute of Microbiology and Virology of the Academy of Sciences of the Ukranian SSR, 252143 Kiev, USSR). Addresses: M. Tsukamura, National Chubu Hospital, Obu, Aichi, Japan; P. Hill, Edinburgh University, UK: D. Jones, Leicester University, UK.

† Strains synthesizing mycobactins.

Table 2. TLC of mycobactins isolated from the genus Rhodococcus

\begin{tabular}{|c|c|c|c|c|c|}
\hline \multirow[b]{2}{*}{ Species } & \multirow{2}{*}{$\begin{array}{l}\text { Percentage } \\
\text { mycobactin } \\
\text { yield* }\end{array}$} & \multicolumn{4}{|c|}{$R_{F}$ values for TLC systems $\dagger$} \\
\hline & & I & III & v & VI \\
\hline R. terrae N659 & $3 \cdot 1$ & $0 \cdot 26$ & $0 \cdot 38$ & $0 \cdot 78$ & 0.48 \\
\hline R. rubropertinctus $\mathrm{N} 4$ & 3.7 & $0 \cdot 26$ & $0 \cdot 40$ & 0.77 & $0 \cdot 46$ \\
\hline R. bronchialis N654 & $2 \cdot 6$ & $0 \cdot 30$ & 0.44 & 0.77 & $0 \cdot 41$ \\
\hline
\end{tabular}

* Yield expressed as a percentage of cell dry weight.

† Solvent systems employed: (I) silica gel G, $20 \mathrm{~cm} \times 20 \mathrm{~cm}$ (Analtech, Newark, USA) developed with petroleum spirit (b.p. $\left.60-80^{\circ} \mathrm{C}\right) /$ ethyl acetate/n-butanol $(2: 3: 3$, by vol.); (III) high performance thin-layer plates, $10 \mathrm{~cm} \times 10 \mathrm{~cm}$, including a $2.5 \times 10 \mathrm{~cm}$ concentrating zone (Merck, 13748) developed with same solvents as system I; (V) plates as for system I but using methanol/ethyl acetate $(4: 1, \mathrm{v} / \mathrm{v})$ for development; (VI) plates as for system I but using propan-1-ol as solvent (Hall \& Ratledge, 1984, 1985).

glucose/yeast extract broth with thiamin $\left(1 \mu \mathrm{g} \mathrm{m \textrm {l } ^ { - 1 }}\right)$. Growth was at $30^{\circ} \mathrm{C}$ with orbital shaking (200 r.p.m.) for 4 to $5 \mathrm{~d}$, after which time a $0.2 \mathrm{ml}$ sample was removed and inoculated on glycerol/asparagine medium solidified with $2 \%(\mathrm{w} / \mathrm{v})$ Lab. M agar (London Analytical and Bacteriological Media, London, UK) as previously described (Hall \& Ratledge, 1982). Under such conditions the bacteria were stressed for iron and so were encouraged to synthesize the iron-chelating compound mycobactin. Initially five plates $(9 \mathrm{~cm}$ diam.) were inoculated for each strain. However, where mycobactin synthesis was low or not evident, 20 plates were used. $R$. rhodnii and $R$. coprophilus failed to grow readily on glycerol/asparagine medium unless glucose $\left(10 \mathrm{~g}^{-1}\right)$ was added.

Mycobactin isolation and characterization. Bacteria were harvested when growth was confluent. Mycobactins were isolated and yields determined following partial purification (Hall \& Ratledge, 1982, 1984). Those strains which consistently failed to produce any mycobactin on solid media were grown in 2 litre iron-deficient glycerol/asparagine medium (Ratledge \& Hall, 1971) and shaken at $30^{\circ} \mathrm{C}$ at 200 r.p.m.

Mycobactins were initially analysed by thin-layer chromatography (TLC), in a single dimension, employing a range of systems previously described in detail (Table 2; Hall \& Ratledge, 1984, 1985). High-performance liquid chromatography (HPLC) analysis of the mycobactins was done using a Spectra-Physics SP8000 instrument (Hall \& Ratledge, 1984, 1985) 


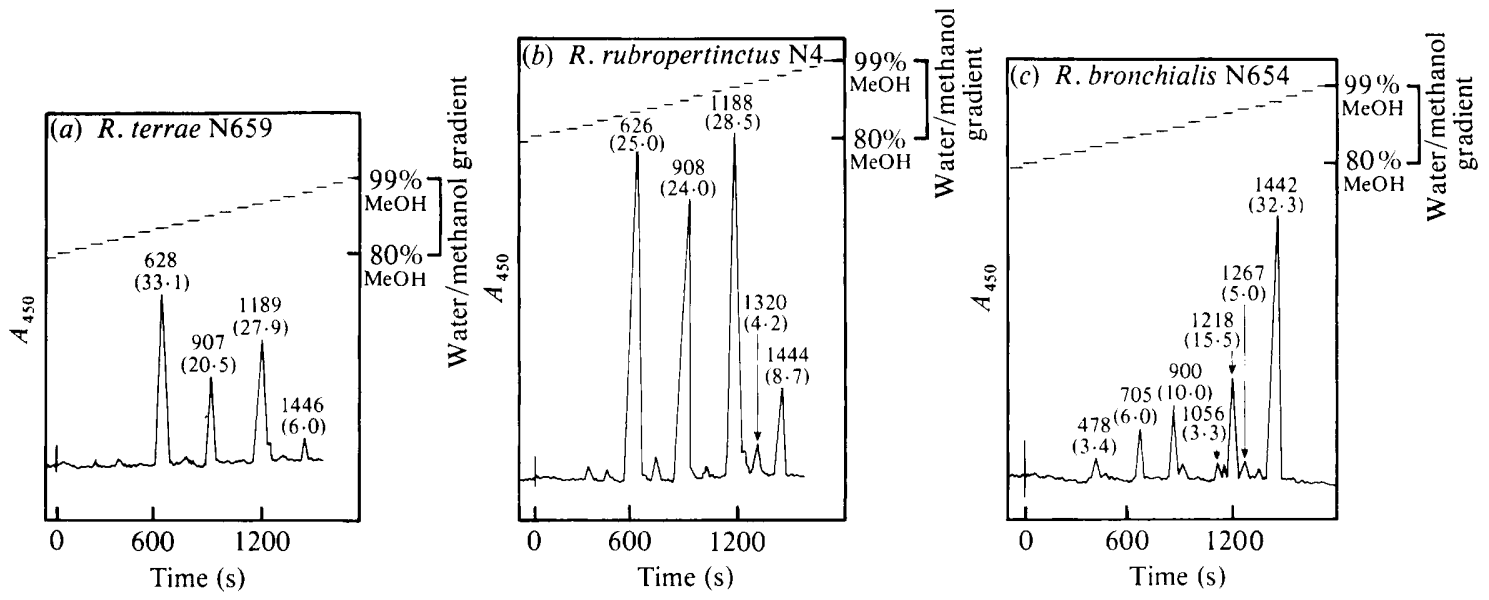

Fig. 1. HPLC of mycobactins isolated from $(a) R$. terrae N659, (b) R. rubropertinctus N4 and (c) $R$. bronchialis $\mathrm{N} 654$. Peaks are labelled with retention times in seconds and percentage peak areas are given, in parentheses, where $>3 \%$ of final chromatogram. Separation was achieved using a Lichrosorb RP18 reverse-phase column with a solvent gradient changing from methanol/water $(80: 20, \mathrm{v} / \mathrm{v})$ over 30 min to methanol alone (Hall \& Ratledge, 1985).

\section{RESULTS}

Mycobactins were synthesized only by $R$. terrae, $R$. rubropertinctus and $R$. bronchialis and were characterized by TLC and HPLC (Table 2 and Fig. 1). Examination of the mycobactins isolated by TLC showed that they migrated as a single component in each of four different solvent systems (Table 2). In each case, the $R_{F}$ values of the mycobactins from $R$. terrae and $R$. rubropertinctus were close, if not identical. Mycobactins from $R$. bronchialis could be readily differentiated in three of the four systems employed. On examination by HPLC (Fig. 1) the mycobactins could be separated into a number of components, thus providing characteristic 'fingerprints' which appear to be highly species-specific. Again the mycobactins from $R$. terrae and $R$. rubropertinctus showed close similarity, the majority of peaks having identical retention times. However, the proportions of each peak present clearly differed. $R$. bronchialis mycobactin again could be rapidly differentiated from that of the other producing species.

None of the remaining Rhodococcus spp. examined produced a detectable mycobactin (limit of detection about $0.26 \mu \mathrm{g}$ on TLC and $1 \mathrm{ng}$ on HPLC) even following bulk growth on solidified medium or in liquid culture under conditions of strict iron-limitation (see Methods).

\section{DISCUSSION}

The results of the present study provide further evidence of the heterogeneity of the genus Rhodococcus. Preliminary work (Ratledge \& Patel, 1976a) showed that a few strains, later classified as rhodococci (Goodfellow \& Alderson, 1977), produced no lipid-soluble iron-binding compounds, whereas a single strain classified as 'Gordona' rubra did synthesize such a molecule. In the present study only those species previously assigned to the genus 'Gordona' synthesized a detectable mycobactin, i.e. $R$. terrae ('Gordona' terrae), $R$. bronchialis ('G.' bronchialis) and $R$. rubropertinctus (syn. $R$. corallinus $\equiv$ ' $G$.' rubra). The mycobactins produced by $R$. terrae and $R$. rubropertinctus appeared to be identical, confirming earlier serological data (Ivshina et al., 1982), but that of $R$. bronchialis was clearly different. The remaining species in the genus did not synthesize any detectable amount of mycobactin.

This apparent division in the genus Rhodococcus is also supported by chemical and serological data. Mycolic acids, long-chain 2-branched 3-hydroxy fatty acids, isolated from $R$. terrae, $R$. bronchialis and $R$. rubropertinctus have between 48 and 66 carbon atoms. These strains also contain dihydrogenated menaquinones with nine isoprene units. On the other hand, $R$. 
coprophilus, $R$. erythropolis, $R$. equi, $R$. rhodnii, $R$. rhodochrous and $R$. ruber produce shorter-chain mycolic acids $\left(\mathrm{C}_{30}\right.$ to $\left.\mathrm{C}_{52}\right)$ and have, predominantly, menaquinones with eight isoprene units. The mycolic acids of $R$. luteus and $R$. maris have not yet been examined but their major menaquinone is the MK-8( $\left.\mathrm{H}_{2}\right)$ type (Minnikin \& Goodfellow, 1980; Collins et al., 1982; Goodfellow \& Cross, 1984). The two groups can also be differentiated on the basis of delayed skin test reactions on sensitized guinea pigs and also by PAGE of bacterial extracts (Hyman \& Chaparas, 1977).

It is possible that further studies might reinforce the separation between the two aggregate taxa, as indicated by the presence and absence of mycobactin, and hence raise the question of whether the two groups can be contained within one genus.

We wish to thank Mrs Janet Stephenson for assistance with media preparation and Dr M. Goodfellow who kindly provided all the strains examined. R. M. H. gratefully acknowledges the support of a grant from the Medical Research Council.

\section{REFERENCES}

Collins, M. D., Goodfellow, M. \& Minnikin, D. E. (1982). A survey of the structures of mycolic acids in Corynebacterium and related taxa. Journal of General Microbiology 128, 129-149.

Goodfellow, M. \& Alderson, G. (1977). The actinomycete-genus Rhodococcus: a home for the 'rhodochrous' complex. Journal of General Microbiology 100, 99-122.

GoOdFEllow, M. \& Cross, T. (1984). Classification. In The Biology of the Actinomycetes, pp. 74-94. Edited by M. Goodfellow, M. Mordarski \& S. T. Williams. London: Academic Press.

Goodfellow, M. \& Minnikin, D. E. (1981). The genera Nocardia and Rhodococcus. In The Prokaryotes: A Handbook of Habitats, Isolation and Identifcation of Bacteria, vol. II, pp. 2016-2027. Edited by M. P. Starr, H. Stolp, H. G. Trüper, A. Balows \& H. G. Schlegel. Berlin: Springer Verlag.

Goodfellow, M. \& ORChaRd, V. A. (1974). Antibiotic sensitivity of some nocardioform bacteria and its value as a criterion for taxonomy. Journal of General Microbiology 83, 375-387.

Goodfellow, M. \& SchaAl, K. P. (1979). Identification methods for Nocardia, Actinomadura and Rhodococcus. In Identification Methods in Microbiology, pp. 261-276. Edited by F. A. Skinner \& D. W. L. Lovelock. London: Academic Press.

GoRdon, R. E. \& MiHM, J. M. (1962). Identification of Nocardia caviae (Erikson) nov. comb. Annals of the New York Academy of Sciences 98, 628-636.

HaLl, R. M. \& RatledGe, C. (1982). A simple method for the production of mycobactin, the lipid soluble siderophore, from mycobacteria. FEMS Microbiology Letters 15, 133-136.

Hall, R. M. \& Ratledge, C. (1984). Mycobactins as chemotaxonomic characters for some rapidly-growing mycobacteria. Journal of General Microbiology 130, 1883-1892.

Hall, R. M. \& Ratledge, C. (1985). Equivalence of mycobactins from Mycobacterium senegalense, Mycobacterium farcinogenes and Mycobacterium fortuitum. Journal of General Microbiology 131, 1691 1696.
Hyman, I. S. \& Chaparas, S. D. (1977). A comparative study of the 'rhodochrous' complex and related taxa by dolayed-type skin reactions on guinea pigs and by polyacrylamide gel electrophoresis. Journal of General Microbiology 100, 363-371.

Ivshina, I. B., Kevorkov, N. N., Koblova, I. V., Nesterenko, O. A., Kvasnikov, E. I. \& Kasumova, S. A. (1982). Identification of bacteria of the genus Rhodococcus. Microbiology 51, 528-533.

Minnikin, D. E. \& Goodfellow, M. (1980). Lipid composition in the classification and identification of acid-fast bacteria. In Microbiological Classification and Identification, pp. 189-256. Edited by M. Goodfellow \& R. G. Board. London: Academic Press.

RATLEDGE, C. \& HaLl, M. J. (1971). Influence of metal ions on the formation of mycobactin and salicylic acid in Mycobacterium smegmatis grown in static culture. Journal of Bacteriology 108, 312-319.

Ratledlge, C. \& Patel, P. V. (1976a). Lipid-soluble, iron-binding compounds in Nocardia and related organisms. In The Biology of the Nocardiae, pp. 372 385. Edited by M. Goodfellow, G. H. Brownell \& J. A. Serrano. London: Academic Press.

Ratledge, C. \& Patel, P. V. (1976b). The isolation, properties and taxonomic relevance of lipid-soluble, iron-binding compounds (the nocobactins) from Nocardia. Journal of General Microbiology 93, 141152.

Tsukamura, M. (1971). Proposal for a new genus, Gordona, for slightly acid-fast organisms occurring in sputa of patients with pulmonary disease and in soil. Journal of General Microbiology 66, 15-26.

TsuKamuRa, M. (1974). A further numerical taxonomic study of the rhodochrous group. Japanese Journal of Microbiology 18, 37-44.

Wellington, E. M. H. \& Williams, S. T. (1978). Preservation of actinomycete inoculum in frozen glycerol. Microbios Letters 6, 151-157.

ZOPF, W. (1891). Über Ausscheidung von Fettfarbstoffen [Lipochromen] seitens gewisser Spaltpilze. Bericht der Deutschen botanischen Gesellschaft 9, 22-28. 